\title{
Embedded aspect in L2 acquisition: Evidence from L1- Russian learners of Greek
}

\author{
Sviatlana Karpava, Kleanthes K. Grohmann \\ Department of English Studies, University of Cyprus, Cyprus \\ https://doi.org/10.36505/ExLing-2010/03/0021/000141
}

\begin{abstract}
This work investigates first-language (L1) influence on second-language (L2) acquisition of embedded aspect, comparing participants with homogeneous L1 background (Russian) in Greece (L2 Standard Modern Greek) and Cyprus (L2 Cypriot Greek), where verb complementation takes a finite form instead of an infinitival as in Russian. The focus of the experimental study is on those embedded sentential environments which allow only perfective aspect in Greek but either perfective or imperfective in Russian. The findings are taken to support the Full Transfer/Full Access Hypothesis, according to which aspect is part of Universal Grammar; L2 learners can reach native-like attainment due to access to UG, while at the initial stage of L2 acquisition transfer from L1 into L2 takes place.
\end{abstract}

Key words: acquisition, cross-linguistic interference, embedded aspect, imperfective, perfective.

\section{Introduction}

According to the Interpretability Hypothesis (Tsimpli 2003), aspect is a grammaticalized, interpretable feature in Greek relevant to the syntax-semantics and the syntax-discourse interfaces. This study investigates L1 influence on L2 acquisition of aspect, comparing participants with homogeneous L1 background (Russian) in Mainland Greece (L2 Standard Modern Greek) and Cyprus (L2 Cypriot Greek).

In both varieties of Modern Greek, Standard Modern Greek (SMG) and Cypriot Greek (CG), verb complementation takes a finite form instead of an infinitival form as in Russian. The particle $n a$, traditionally analyzed as a subjunctive marker (Veloudis and Philippaki-Warburton 1983, Roussou 2009), introduces subjunctive clauses; the $n a$-clause is a complement clause controlled by the main verb. Aspect in the subjunctive subordinate $n a$-clauses depends on the kind of verb in the main clause (Malagardi 1993). According to Moser (1993), there is an interaction between lexical and grammatical aspect that influences the aspect of the embedded verb in na-clauses. Four lexical aspects (states, activities, achievements, and accomplishments) interact with two grammatical aspects (perfective and imperfective).

In Russian, if the complementation is infinitival, the subject of the main clause and the embedded clause should be the same. If the complementation

ExLing 2010: Proceedings of 3rd Tutorial and Research Workshop on Experimental Linguistics, 25-27 August, Athens, Greece 
is with a finite verb, the complementizer čtoby 'in order to' is used; there is a restriction on tense of the embedded finite verb: The verb should be only in the past, and the subjects of the main and embedded clauses should be different.

\section{The Study}

276 participants took part in the study: 75 bilingual Russian-CG speakers (25 adults, 50 children), 63 bilingual Russian-SMG speakers (13 adults, 50 children), and two control groups of 75 monolingual SMG speakers (25 adults, 50 children) and 63 monolingual CG speakers (25 adults, 38 children).

The participants were offered a sentence picture-matching task and an elicited production task. They were expected to choose (i) perfective in embedded environments which allow only perfective aspect in Greek but either perfective or imperfective in Russian: with an accomplishment main verb that has a continuous interpretation (prospathusa 'try'), a perfective non-ingressive state main verb (fovithika 'be afraid'), a perfective ingressive state main verb (boresa 'be able'), a perfective volitional verb (ithela 'want'), and an activity verb expressing a purpose or a goal with $n a$ being a short form of gia na 'in order to'; and (ii) imperfective aspect of the complement verb in sentences where both Russian and Greek allow only imperfective: when the main verb is inchoative (arhise 'start').

\section{Results}

Not surprisingly, native speakers performed better than the bilingual Russian-SMG and Russian-CG speakers in both Greece and Cyprus. In addition, and perhaps more surprising, the performance of both monolingual and bilingual groups was better for SMG-speakers in Greece than the corresponding groups of CG-speakers in Cyprus.

According to an ANOVA (means) statistical analysis, there is a statistically significant difference between all groups except of the monolingual SMG and CG: $t$-value -0.363 , df $=136$, prob. $=.7174$. According to the two-sample $t$-test between percentages, there is a statistically significant difference only between the SMG monolingual and the Russian-CG groups: $t$-value $1.964, \mathrm{df}=136$, prob. $=.05$.

In both countries, the test production of monolingual adults was better than bilingual adults. Bilingual Russian-CG adults performed better than bilingual Russian-SMG speakers, while monolingual SMG adults performed better than $C G$ adults. 
Embedded aspect in L2 acquisition

Table 1. Non-target test production of the groups.

\begin{tabular}{|l|l|l|l|l|}
\hline \hline & GREECE & CYPRUS \\
\hline $\begin{array}{l}\text { Non-target } \\
\text { Production }\end{array}$ & $\begin{array}{l}\text { 63 Russian-SMG } \\
\text { adults + children }\end{array}$ & $\begin{array}{l}\text { 63 SMG adults } \\
\text { + children }\end{array}$ & $\begin{array}{l}\text { 75 Russian-CG } \\
\text { adults + children }\end{array}$ & $\begin{array}{l}\text { 75 CG adults } \\
\text { + children }\end{array}$ \\
\hline prospathuse & $1.21 \%$ & $0.33 \%$ & $1.94 \%$ & $0.38 \%$ \\
\hline fovithike & $3.30 \%$ & $1.10 \%$ & $3.66 \%$ & $2.46 \%$ \\
\hline mborese & $0.97 \%$ & $0.28 \%$ & $1.35 \%$ & $0.16 \%$ \\
\hline gia na & $1.52 \%$ & $1.21 \%$ & $2.48 \%$ & $1.20 \%$ \\
\hline arhise & $1.52 \%$ & $0.33 \%$ & $2.09 \%$ & $0.40 \%$ \\
\hline ithele & $0.90 \%$ & $0.11 \%$ & $1.16 \%$ & $0.31 \%$ \\
\hline TOTAL & $9.43 \%$ & $3.37 \%$ & $12.70 \%$ & $4.94 \%$ \\
\hline
\end{tabular}

The perfective condition was more problematic than imperfective for nonnative groups, presumably since in L1 Russian both perfective and imperfective aspect are possible, so either positive or negative transfer might take place.

The most problematic types of the main verbs for all groups were fovithike 'afraid', activity verbs with gia na 'in order to' (perfective condition), and arhise 'start' (imperfective condition).

In both countries, monolingual children performed better than bilingual children and the test production of SMG and Russian-SMG children was better than that of CG and Russian-CG children.

Table 2. Non-target test production: adults vs. children

\begin{tabular}{|l|l|l|l|l|}
\hline \hline \multicolumn{2}{|l|}{} & GREECE & \multicolumn{2}{l|}{ CYPRUS } \\
\hline $\begin{array}{l}\text { non-target } \\
\text { production }\end{array}$ & $\begin{array}{l}\text { 13 Russian-SMG } \\
\text { adults }\end{array}$ & $\begin{array}{l}\text { 25 SMG } \\
\text { adults }\end{array}$ & $\begin{array}{l}\text { 25 Russian-CG } \\
\text { adults }\end{array}$ & 25 CG adults \\
\hline TOTAL & $28.41 \%$ & $2.33 \%$ & $15.7 \%$ & $4.38 \%$ \\
\hline $\begin{array}{l}\text { non-target } \\
\text { production }\end{array}$ & $\begin{array}{l}50 \text { Russian-SMG } \\
\text { children }\end{array}$ & $\begin{array}{l}38 \text { SMG } \\
\text { children }\end{array}$ & $\begin{array}{l}50 \text { Russian-CG } \\
\text { children }\end{array}$ & $\begin{array}{l}50 \text { CG } \\
\text { children }\end{array}$ \\
\hline TOTAL & $4.5 \%$ & $4.05 \%$ & $11.16 \%$ & $5.22 \%$ \\
\hline \hline
\end{tabular}

Bilingual children, both in Greece and in Cyprus, performed better than adults, while monolingual adults performed better than children.

L2 children (both Russian-SMG and Russian-CG) get systematic language instruction before or within the critical period; L2 adults on the other hand may not have a systematic language instruction and the language input is far beyond the critical period.

The findings of the study support the Full Transfer/Full Access Hypothesis (Schwartz and Sprouse 1994, Slabakova 2005): Aspect is part of Universal Grammar and L2 learners can reach native-like attainment due to the access to UG, while transfer from L1 into L2 takes place at the initial stage of L2 acquisition. This study provides evidence in support of the Full Transfer/Full 
Access Hypothesis by investigating how learners with a homogeneous L1 background acquire L2 aspect in bi-dialectal settings (SMG and CG).

The non-target test production by the Russian-CG group might be explained by the fact that Russian-SMG participants have more years of exposure to L2 in comparison to Russian-CG, or it might be due to the diglossic or bilingual-like situation in Cyprus that influences language acquisition and learning in very interesting ways and puts subjects at a disadvantage similar to what is observed in delayed language development.

\section{References}

Malagardi, I. 1993. Problems of Greek aspect morphology and the identification of projection for Tense and Aspect. In Philippaki-Warburton, I., Nicolaidis, K. and Sifianou, M. (eds.), Themes in Greek Linguistics, 161-169. Amsterdam, John Benjamins.

Moser, A. 1993. The interaction of lexical and grammatical aspect in Modern Greek. In Philippaki-Warburton, I., Nicolaidis, K. and Sifianou, M. (eds.), Themes in Greek Linguistics, 137-145. Amsterdam, John Benjamins.

Roussou, A. 2009. Selecting complementizers. Lingua 119, 1811-1836.

Schwartz, B.D., Sprouse, R. 1994. Word order and nominative case in nonnative language acquisition: A longitudinal study of (L1 Turkish) German interlanguage. In Hoekstra, T. and Schwartz, B.D. (eds.), Language Acquisition Studies in Generative Grammar, 317-368. Amsterdam, John Benjamins.

Slabakova, R. 2005. What is so difficult about telicity marking in L2 Russian? Bilingualism: Language and Cognition, 8, 63-77.

Tsimpli, I.M. 2003. Clitics and determiners in L2 Greek. Proc. of Generative Approaches to Second Language Acquisition. Somerville, Mass., Cascadilla Press.

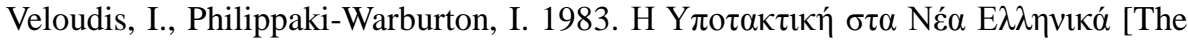
subjunctive mood in Modern Greek]. Studies in Greek Linguistics, 151-169. 